\title{
Retraction Note: Receptor tyrosine kinase inhibitor Sunitinib and integrin antagonist peptide HM-3 show similar lipid raft dependent biphasic regulation of tumor angiogenesis and metastasis
}

\author{
Jialiang Hu${ }^{1,2+}$, Wenjing Wang ${ }^{1 \dagger}$, Chen Liu ${ }^{1,2}$, Mengwei $\mathrm{Li}^{1,2}$, Edouard Nice ${ }^{3}$ and Hanmei $\mathrm{Xu}^{1,2^{*}}$
}

\section{Retraction Note: J Exp Clin Cancer Res \\ https://doi.org/10.1186/s13046-019-1324-7}

The authors have retracted this article [1] because the bands shown in Fig. 5 panel D for GTP-RhoA/Control, GTP-RhoA/Sunitinib (2 and $64 \mathrm{nM}$ ) and GTP-RhoA/ HM-3 (4.5 and $72 \mathrm{uM}$ ) are not data generated as part of this study. All authors agree to this retraction.

\begin{abstract}
Author details
'State Key Laboratory of Natural Medicines, Ministry of Education, China Pharmaceutical University, Nanjing 210009, People's Republic of China. ${ }^{2}$ The Engineering Research Center of Synthetic Polypeptide Drug Discovery and Evaluation of Jiangsu Province, Nanjing 211198, People's Republic of China. ${ }^{3}$ Department of Biochemistry and Molecular Biology, Monash University,
\end{abstract} Clayton, VIC 3800, Australia.

Published online: 17 February 2020

\section{Reference}

1. Hu J, Wang W, Liu C, et al. Receptor tyrosine kinase inhibitor Sunitinib and integrin antagonist peptide HM-3 show similar lipid raft dependent biphasic regulation of tumor angiogenesis and metastasis. J Exp Clin Cancer Res. 2019;38:381. https://doi.org/10.1186/s13046-019-1324-7.

The original article can be found online at https://doi.org/10.1186/s13046019-1324-7

*Correspondence: 13913925346@126.com

†jialiang Hu and Wenjing Wang contributed equally to this work.

${ }^{1}$ State Key Laboratory of Natural Medicines, Ministry of Education, China

Pharmaceutical University, Nanjing 210009, People's Republic of China

${ }^{2}$ The Engineering Research Center of Synthetic Polypeptide Drug Discovery

and Evaluation of Jiangsu Province, Nanjing 211198, People's Republic of

China

Full list of author information is available at the end of the article

(c) The Author(s). 2020 Open Access This article is distributed under the terms of the Creative Commons Attribution 4.0 International License (http://creativecommons.org/licenses/by/4.0/), which permits unrestricted use, distribution, and reproduction in any medium, provided you give appropriate credit to the original author(s) and the source, provide a link to the Creative Commons license, and indicate if changes were made. The Creative Commons Public Domain Dedication waiver (http://creativecommons.org/publicdomain/zero/1.0/) applies to the data made available in this article, unless otherwise stated. 